Article

\title{
Limited Reliability of the Molecular Detection of Plasmodium spp. from Incubated Blood Culture Samples for Forensic Purposes
}

\author{
Felix Weinreich ${ }^{1}(\mathbb{D})$, Ralf Matthias Hagen ${ }^{2}\left(\mathbb{D}\right.$, Wibke Loag $^{3}\left(\mathbb{D}\right.$, Oumou Maïga-Ascofaré ${ }^{3,4}$, Denise Dekker $^{3,5}$ De $^{\text {, }}$ \\ Hagen Frickmann $1,6, *,+(\mathbb{D})$ and Ulrike Loderstädt ${ }^{7, *,+}$
}

check for

updates

Citation: Weinreich, F.; Hagen, R.M.; Loag, W.; Maïga-Ascofaré, O.; Dekker, D.; Frickmann, H.; Loderstädt, U. Limited Reliability of the Molecular Detection of Plasmodium spp. from Incubated Blood Culture Samples for Forensic Purposes. Microorganisms 2022, 10, 406. https://doi.org/10.3390/ microorganisms10020406

Academic Editor: Adriana Calderaro

Received: 31 December 2021

Accepted: 8 February 2022

Published: 10 February 2022

Publisher's Note: MDPI stays neutral with regard to jurisdictional claims in published maps and institutional affiliations.

Copyright: () 2022 by the authors. Licensee MDPI, Basel, Switzerland. This article is an open access article distributed under the terms and conditions of the Creative Commons Attribution (CC BY) license (https:// creativecommons.org/licenses/by/ $4.0 /)$.
1 Department of Microbiology and Hospital Hygiene, Bundeswehr Hospital Hamburg, 20359 Hamburg, Germany; Felixweinreich@bundeswehr.org

2 Department of Microbiology and Hospital Hygiene, Bundeswehr Central Hospital Koblenz, 56070 Koblenz, Germany; ralfmatthiashagen@bundeswehr.org

3 Bernhard Nocht Institute for Tropical Medicine Hamburg, 20259 Hamburg, Germany; loag@bnitm.de (W.L.); maiga@bnitm.de (O.M.-A.); dekker@bnitm.de (D.D.)

4 Kumasi Centre for Collaborative Research in Tropical Medicine, College of Health Sciences, KNUST, Kumasi 039-5028, Ghana

5 German Center for Infection Research (DZIF), Partner Site Hamburg-Lübeck-Borstel-Riems, 20359 Hamburg, Germany

6 Institute for Medical Microbiology, Virology and Hygiene, University Medicine Rostock, 18057 Rostock, Germany

7 Department of Hospital Hygiene \& Infectious Diseases, University Medicine Göttingen, 37075 Göttingen, Germany

* Correspondence: frickmann@bnitm.de (H.F.); Ulrike.loderstaedt1@med.uni-goettingen.de (U.L.); Tel.: +49-406-94728743 (H.F.); +49-551-3965709 (U.L.)

+ These authors contributed equally to this work.

Abstract: The suitability of incubated blood culture material for forensic molecular malaria diagnosis was assessed for non-endemic settings for cases in which the differential diagnosis malaria was initially overlooked. For the proof-of-principle assessment, residual blood culture materials from febrile patients from tropical Ghana were investigated by real-time PCR and compared with available historic microscopic results. In 2114 samples, for which microscopical results and real-time PCR results were available, microscopical results comprised 711 P. falciparum detections, 7 P. malariae detections, 1 microscopically not-further-discriminable Plasmodium spp. detection as well as 13 detections of mixed infections comprising 12 cases of $P$. falciparum/P. malariae co-infections and 1 case of a P. falciparum/P. ovale complex co-infection, while real-PCR indicated 558 P. falciparum detections, 95 P. malariae detections, 10 P. ovale complex detections, 1 P. vivax detection and 4 detected P. falciparum/P. malariae co-infections. Concordance of routine microscopy and real-time PCR was imperfect. Using routine microscopy as reference was associated with a seemingly low agreement of positive real-time PCR results of $90.9 \%$. However, if positive samples, either by routine microscopy or real-time PCR or both, were applied as a combined reference, the agreement of positive results obtained with real-time PCR was increased from $74.0 \%$ to $77.9 \%$, while the agreement of positive results obtained with routine microscopy was decreased from $100 \%$ to $85.3 \%$. The predictive value of routine microscopy for negative results in the reference was slightly better with $90.9 \%$ compared to real-time PCR with $86.9 \%$; the concordance between routine microscopy and real-time PCR was imperfect. In conclusion, even suboptimal sample materials such as incubated blood culture materials can be applied for forensic malaria diagnosis, if more suitable sample materials are not available, but the molecular detection rate of positive results in routine microscopy is much lower than previously reported for non-incubated blood.

Keywords: Plasmodium; routine microscopy; molecular diagnosis; blood culture; real-time PCR; test accuracy; test comparison 


\section{Introduction}

Training options to maintain skills in routine malaria microscopy in non-endemic settings are limited because of scarcely available sample material. Morphologically similar species such as Plasmodium vivax, P. ovale curtisi and P. ovale wallikeri tend to be misinterpreted under the microscope [1-3] with more than $10 \%$ misidentification of $P$. vivax and P. ovale complex [1]. P. ovale curtisi and P. ovale wallikeri, in particular, are virtually indistinguishable by routine microscopy. Molecular approaches for the screening of malaria are useful alternatives for resource-rich settings with limited skills of the laboratory personnel in routine malaria microscopy, as molecular approaches such as real-time PCR are easy to standardize and, thus, less investigator-dependent than routine microscopy. Due to the molecular assays' high sensitivity [4-6], nucleic acid amplification tests for malaria are also useful if a correct identification of early infections with low parasitaemia is desired or mixed plasmodial infections need to be excluded [7,8]. Further, molecular approaches such as PCR are more sensitive than antigen testing, including the recently introduced "ultrasensitive rapid diagnostic tests" $[9,10]$. Apart from the diagnostic needs in resource-rich non-endemic settings, the suitability of highly sensitive real-time PCR assays has also been suggested for malaria eradication programs [11-16].

Whole blood and-even more-capillary blood [17] are the optimum materials for the molecular diagnosis of malaria. In contrast, diagnostic attempts with alternative, less invasively collectible specimens were rather disappointing [18]. Of note, more easily storable and transportable sample materials such as dried whole blood spots are less reliable than whole blood, particularly for the diagnosis of low-density P. vivax infections [19]. Alternative sample materials, from which the detection of Plasmodium spp. is basically possible if sensitivity loss is accepted, comprise rapid diagnostic tests [20], scrapes of the blood smears on microscopic slides [21] and even stool samples [22]. In spite of sensitivity limitations, there are circumstances under which the use of sub-optimal sample materials needs to be considered for forensic diagnostics. Therefore, it is useful to assess the diagnostic accuracy of real-time PCR-based malaria diagnosis for such instances. In non-endemic settings, a malaria screening is not a routine procedure if malaria is not suspected in case of symptoms of septic fever, especially if a patient does not mention traveling to areas of malaria endemicity. To identify invasive bacterial infections, blood cultures need to be performed. If a blood culture stays negative 5-7 days after the initiation of incubation and the forensic question of an overlooked malaria arises, it needs to be confirmed as to whether real-time PCR from such a material can reliably detect the abundance or absence of microscopically detectable parasites at the time of sample acquisition. If the answer is yes, it can be forensically decided whether malaria would have been microscopically diagnosed at the time of sample acquisition if this assessment had not been initially overlooked.

Unfortunately, molecular diagnostics from incubated blood culture material are not routinely performed. Standard nucleic acid extraction procedures on this type of sample material are associated with inhibition of the PCR reaction, requiring more laborious sample preparation [23]. Nonetheless, molecular malaria diagnostics from incubated blood culture materials still have to be considered in case of a forensic need. The present study aimed at evaluating the diagnostic reliability of real-time PCR-based molecular malaria diagnoses from incubated blood culture materials as compared to traditional routine microscopy from whole-blood samples.

\section{Materials and Methods}

\subsection{Study Type}

The study was designed as a head-to-head test comparison of malaria microscopy and malaria real-time PCR using historic residual sample materials from previous epidemiological studies in Ghana, which had been conducted between 2007 and 2008 [24-28]. 


\subsection{Residual Sample Materials Applied for the Malaria Real-Time PCR Testing in This Study}

Incubated blood culture material had been collected from a total of $2324 \mathrm{BD}$ (Becton Dickinson, Heidelberg, Germany) blood culture bottles (BACTEC Plus Aerobic/F Medium for adults and BD BACTEC Peds Plus Medium for children) that had been inoculated with blood from febrile Ghanaian patients in the course of a two-year study period from 2007 to 2008 [24-28]. In short, the bottles were filled according to the manufacturer's instructions and incubated at $36{ }^{\circ} \mathrm{C}$ until a positive result was indicated or otherwise for a total of 5 days as detailed elsewhere [24]. Culture-based growth of bacteria succeeded from $12.7 \%$ of the samples, while the inclusion of panbacterial 16S rRNA DNA gene-specific PCR increased the proportion of positive samples to $36.7 \%$ [25]. Residual samples of the collected blood culture material had been stored at $-80{ }^{\circ} \mathrm{C}$ and shipped on dry ice to Germany for molecular assessments.

\subsection{Microscopic Assessment of Freshly Taken EDTA Blood Samples during the Studies in Ghana}

In parallel to the acquisition of those blood culture materials, which were reassessed by malaria real-time PCR over the course of this study, EDTA blood samples from the Ghanaian fever patients had been subjected to routine microscopy of Giemsa-stained [29] thick and thin blood films in order to identify Plasmodium spp. directly. If malaria parasites were detected, species identification had been performed and parasitemia had been determined [30] and indicated as parasites per microliter. The applied protocol for the microscopic mass screening for malaria was suggested and detailed elsewhere [30]. In short, routine microscopy analysis was carried out by an experienced microscopist, comprising examination of 200 oil immersion fields of the thick blood smear $(0.5 \mu \mathrm{L}$ of blood). Parasitemia was estimated on the basis of 8000 leukocytes per $\mu \mathrm{L}$ as described elsewhere [30]. Data on the patients' routine malaria microscopy results had been anonymized for this study.

\subsection{Sample Preparation Prior to PCR Assessment}

Due to the above-mentioned PCR inhibition risk, DNA was extracted by applying a previously described laborious centrifugation-based procedure [24] instead of a commercial standard procedure and stored at $-80^{\circ} \mathrm{C}$. The centrifugation-based procedure, which was in fact more a purification of bacteria as well as of free DNA from the blood culture samples for PCR rather than a traditional nucleic acid extraction, was reported in detail elsewhere [24]. In short, erythrocytes of $1 \mathrm{~mL}$ blood culture sample were sedimented by centrifugation at $140 \times g$ for $10 \mathrm{~min}$, before the supernatant of $800 \mu \mathrm{L}$ was transferred into another tube, while the sediment was discarded. A volume of $400 \mu \mathrm{L}$ double-distilled water was added to the $800 \mu \mathrm{L}$ supernatant to ensure the lysis of remaining erythrocytes. Subsequently, bacterial cells and free DNA within the sample were sedimented by centrifugation at $750 \times g$ for an additional $10 \mathrm{~min}$. After discarding the supernatant, the remaining pellet became resuspended and washed in $1 \mathrm{~mL}$ double-distilled water with additional centrifugation at $750 \times g$ for $10 \mathrm{~min}$. Again, the supernatant was discarded and the pellet was resuspended in $200 \mu \mathrm{L}$ double-distilled water. In a final step, the sample was incubated for $10 \mathrm{~min}$ at $95^{\circ} \mathrm{C}$ to release DNA from bacterial cells. The proof-of-principle of the suitability of this centrifugation approach had been performed with real-time PCRs targeting entero-invasive bacteria [24] as well as with pan-bacterial real-time PCRs [25]. In order to ensure the reproducibility of the centrifugation-based DNA purification approach, repeated incubation of blood culture bottles with different concentrations of the same Salmonella enterica strain had been performed. After incubation until the lag phase of bacterial growth and centrifugation-based purification of DNA as described above, cycle threshold (Ct) values of Salmonella spp.-specific real-time PCR [24] were reproducible in all samples with a standard deviation range of less than 0.5 cycle threshold $(\mathrm{Ct})$ steps both from fresh and from frozen incubated blood culture samples. The effect of freezing, in contrast, resulted in a loss of 2 Ct steps. 


\subsection{Applied Malaria Screening Real-Time PCR Assay}

Screening was performed with a SybrGreen-based non-commercial real-time PCR targeting the 18S rRNA gene of Plasmodium spp. [31]. The primers of the SybrGreenbased screening assay [31] for malaria are provided in Table 1 for readers with interest in molecular details, and the positive control plasmid inserts of the Plasmodium spp. with medical relevance, as applied for the melting temperature definitions, are presented in Appendix A, Table A1. As shown in a recent assessment, the SybrGreen-based screening PCR is associated with a sensitivity of $94.8 \%$ and a specificity of $100.0 \%$ if applied with whole blood, as observed with a sample collection from patients with microscopic and sub-microscopic malaria [32].

\subsection{Confirmatory Malaria Real-Time PCR Assay and Conditions under Which This Confirmation Was Performed}

For cases of uncertain or contradictory non-commercial SybrGreen-based real-time PCR screening results, differentiation at the species level and screening for infections with more than one Plasmodium species were attempted using a limited number of 605 available reactions of the RealStar Malaria S\&T PCR Kit 1.0 (Altona Diagnostics, Hamburg, Germany), which included an inhibition control reaction for those 605 samples. The assay was applied as described by the manufacturer's instructions and as detailed elsewhere [2,32]. This kind of confirmation testing was applied for the following indications in declining order of priority: (1) SybrGreen-based screening PCR reactions with distorted melting curves within the expected temperature range potentially indicating infections with more than one Plasmodium species or non-specific reactions, (2) samples with positive routine microscopy but negative SybrGreen-based screening PCR in order to discriminate PCR inhibition events from potentially false-positive microscopic results, and (3) lowest-priority samples with low cycle threshold values (Ct 15-25) and melting curves suggesting P. falciparum mono-infection in SybrGreen-based screening PCR, as such situations are conspicuous for "hidden" double infections with highly differing proportions of parasitemia, as shown previously [2]. If SybrGreen-based screening PCR and commercial Altona Diagnostics confirmation PCR were performed due to distorted melting curves in the SybrGreen-based screening PCR and conflicting results of both were seen, the results of the commercial Altona Diagnostics differentiation PCR were accepted.

\subsection{Differentiation PCR Assay for the Discrimination of P. ovale wallikeri and P. ovale curtisi}

In case of detection of the P. ovale complex either by routine microscopy, using the noncommercial SybrGreen-based screening assay, or with the commercial Altona Diagnostics differentiation assay, a non-commercial duplex real-time PCR, as described before [33] and as associated with high diagnostic accuracy in comparison to competitor assays $[3,34,35]$, was added for the discrimination of P. ovale curtisi and P. ovale wallikeri. The oligonucleotides of this latter differentiation assay are given in Table 1, and the positive control plasmids are included in Appendix A, Table A2. The P. ovale complex differentiation assay was performed as described previously [3].

\subsection{Inclusion and Exclusion Criteria}

Samples were included in the assessment if at least enough sample material for the SybrGreen-based screening PCR, i.e., a $5 \mu \mathrm{L}$ volume, was available, leading to the exclusion of three samples. The lack of routine microscopy results was no exclusion criterion for the PCR assessment. Samples with lacking microscopic results were nevertheless included in the molecular prevalence assessment for the sample collection. 
Table 1. Oligonucleotide sequences of the applied non-commercial malaria real-time PCRs.

\begin{tabular}{|c|c|c|c|c|c|}
\hline $\begin{array}{l}\text { Forward Primer } \\
\text { Name }\end{array}$ & $\begin{array}{l}\text { Forward Primer } \\
\text { Sequence }\end{array}$ & $\begin{array}{l}\text { Reverse Primer } \\
\text { Name }\end{array}$ & $\begin{array}{l}\text { Reverse Primer } \\
\text { Sequence }\end{array}$ & Probe Name & Probe Sequence \\
\hline \multicolumn{6}{|c|}{ SybrGreen-based generic Plasmodium spp.-specific real-time PCR targeting the 18S rRNA gene used for screening, according to Mangold et al. [32]. } \\
\hline PL1473F18 & $\begin{array}{l}5^{\prime} \text {-TAACGAACGA- } \\
\text { GATCTTAA-3' }\end{array}$ & L1679R18 & $\begin{array}{l}\text { 5'-GTTCCTCTAA- } \\
\text { GAAGCTTT-3' }\end{array}$ & n.a. & n.a. \\
\hline \multicolumn{6}{|c|}{$\begin{array}{c}\text { Dual hybridization probe real-time PCR for the discrimination of P. ovale curtisi and P. ovale wallikeri targeting the ssu rRNA, according to } \\
\text { Bauffe et al. [34] }\end{array}$} \\
\hline POF & $\begin{array}{c}\text { 5'-ATAAAC- } \\
\text { TATGCCGACTAG } \\
\text { GTT-3' }\end{array}$ & POR & $\begin{array}{c}\text { 5'-ACTTTGAT- } \\
\text { TTCTCATAAGGT- } \\
\text { ACT-3' }\end{array}$ & pPOW $^{2}$ & $\begin{array}{c}\text { 5'-TTCCTTTCGGG- } \\
\text { GAAATTTCTTA } \\
\text { GA-3' } \\
\text { 5'-AATTCCTTTT- } \\
\text { GGAAATTTCT } \\
\text { TAGATTG-3' }\end{array}$ \\
\hline
\end{tabular}

n.a. $=$ not applicable. $\mathrm{pPOC}=$ probe for the detection of $P$. ovale curtisi. $\mathrm{pPOW}=$ probe for the detection of P. ovale wallikeri. ${ }^{1}$ FAM and BHQ1 were used as reporter and quencher, respectively. ${ }^{2} \mathrm{JOE}$ and BHQ1 were used as reporter and quencher, respectively.

\subsection{Assessment Strategy for the Obtained Data}

Considering the well-known sensitivity differences of real-time PCR and routine microscopy [4-8,32], combined references were applied for the agreement and concordance assessment. In a first step, microscopic results were considered as the reference for the calculation of the agreement of positive and negative results, as well as predictive values of PCR for positive and negative results in the reference. Keeping the known reduced sensitivity of routine microscopy compared to PCR in mind [4-8,32], a second calculation was added, which considered a sample to be positive for malaria if at least a positive microscopic result or a positive PCR result were available to calculate agreement of positive results as well as predictive values of PCR and routine microscopy for negative results obtained with this combined reference.

Next to qualitative real-time PCR results, semi-quantitative results based on cycle threshold $(\mathrm{Ct})$ values as well as microscopically quantified parasitemia were recorded and descriptively assessed. The correlation (Spearman $\mathrm{r}$ ) of $\mathrm{Ct}$ values obtained with the SybrGreen-based screening PCR and microscopically observed parasitemia was calculated.

\subsection{Ethics}

For this study, ethical clearance by the medical association of Hamburg, Germany (reference number: WF-011/19; obtained on 11 March 2019) allowed the anonymous use of residual sample volumes, which were labeled with laboratory-derived sample-ids, without further requirements such as informed consent. Anonymization was performed in line with national German laws, i.e., the data protection regulation ("Datenschutzgrundverordnung"). Since the data and sample materials had been anonymized, no patient-specific details can be connected to the results presented here, which is an admitted deviation from the STARD (Standards for Reporting Diagnostic Accuracy) criteria [36].

\section{Results}

\subsection{Overall Assessment}

From the 2321 samples included in the analysis, results of the microscopic analysis were available for 2114 samples. Within the 207 samples without microscopic results, real-time PCR identified 58 samples containing Plasmodium spp. DNA, comprising $44 \times$ P. falciparum, $12 \times$ P. malariae, $1 \times P$. vivax and $1 \times$ P. ovale complex. Those 207 samples were excluded from the test comparison but all PCR-based detections are indicated in Appendix A, Table A3. A flowchart indicating the exclusions is provided in Table 2. 
Table 2. Flow-chart indicating the diagnostic workflow with residual materials from incubated blood culture samples from a previous Ghanaian study [24-28] as detailed above in the "Materials and Methods" chapter.

2321 Blood Culture Samples from a Ghanaian Epidemiological Study Included, of Which 2114 Had Microscopical Results from Concomitantly Taken Whole-Blood Samples

\begin{tabular}{|c|}
\hline$\downarrow$ \\
\hline $\begin{array}{l}\text { Assessment of all } 2321 \text { blood culture sample residual volumes by SybrGreen-based } \\
\text { non-commercial malaria real-time PCR screening }\end{array}$ \\
\hline$\downarrow$ \\
\hline $\begin{array}{l}\text { Inclusion of } 605 / 2321(26.1 \%) \text { blood culture sample residual volumes (comprising } 122 \text { samples } \\
\text { without available microscopic result) into confirmatory commercial Altona Diagnostics real-time } \\
\text { PCR testing, if the following conditions were met: }\end{array}$ \\
\hline $\begin{array}{l}\text { - Samples were microscopically positive but negative in SybrGreen-based screening PCR } \\
\text { - }(n=211) ; \\
\text { Distorted melting curves of the SybrGreen-based screening PCR within the expected } \\
\text { temperature range did not allow unambiguous interpretation }(n=229) ; \\
\text { Plasmodium falciparum mono-infections were detected by SybrGreen-based screening PCR } \\
\text { with low cycle threshold values }(15-25) \text { and, thus, mixed plasmodial infections with severely } \\
\text { dysbalanced parasitemia could not be excluded by melting curve analysis alone }(n=165) \text {. }\end{array}$ \\
\hline$\downarrow$ \\
\hline $\begin{array}{l}\text { Non-commercial duplex real-time PCR for the discrimination of P. ovale wallikeri and P. ovale curtisi } \\
\text { in case of P. ovale complex detections by real-time PCR or by routine microscopy }(n=11)\end{array}$ \\
\hline
\end{tabular}

In a total of 732 out of the 2114 included cases, malaria was microscopically diagnosed with 711 P. falciparum detections, 7 P. malariae detections, 1 microscopically not-furtherdiscriminable Plasmodium spp. detection and 13 detections of mixed infections comprising 12 cases of $P$. falciparum/P. malariae co-infections and 1 case of a $P$. falciparum/P. ovale complex co-infection.

In a total of 211 microscopically positive cases, SybrGreen PCR-based screening was negative and, thus, commercial hybridization probe-based Altona Diagnostics confirmation PCR was added to assess the relevance of sample inhibition within these negatively tested samples. Relevant PCR inhibition was not recorded, but plasmodial DNA was recorded only in a minority of 69 out of 211 samples by confirmation testing with the Altona Diagnostics assay as well.

Out of 740 initially positive SybrGreen-screening PCR results, 229 showed distorted melting curves in the expected temperature range of Plasmodium-specific amplicons, so commercial Altona Diagnostics real-time multiplex PCR was applied as a specificity control. From those 229 cases, 14 SybrGreen-based screening PCR signals were excluded as nonspecific due to lacking confirmation by commercial hybridization probe-based Altona Diagnostics real-time PCR. In total, four cases of mixed infections could be confirmed using the commercial molecular approach by Altona Diagnostics among the samples with distorted melting curves in the SybrGreen-based screening PCR, each comprising combinations of P. falciparum and P. malariae.

Finally, exclusion of infections due to different Plasmodium spp. in samples with low cycle threshold $(\mathrm{Ct}$ ) values (assessed range from $\mathrm{Ct} 15$ to $\mathrm{Ct} 25$ ) in SybrGreen-based screening PCR and melting curves indicating P. falciparum by applying commercial Altona Diagnostics multiplex real-time PCR succeed in 165 instances. Multi-infections were not recorded. Of note, 12 samples with melting curves unambiguously indicating $P$. falciparum in the SybrGreen-based screening assay were missed by the commercial hybridization probe-based Altona Diagnostics real-time PCR approach.

Considering the abovementioned corrections for specificity to control uncertain results of the SybrGreen-based screening PCR, which are detailed in Table 3, real-time PCR resulted in $558 P$. falciparum detections, 95 P. malariae detections, $10 P$. ovale complex detec- 
tions, 1 P. vivax detection and 4 detected $P$. falciparum / P. malariae co-infections within the 2114 included samples. Imperfect concordance of PCR and routine microscopy was also recorded at the species level as shown in Table 4 and in Appendix A, Table A3.

Table 3. Applied interpretation algorithm for the confirmatory testing applying the commercial hybridization probe-based Altona Diagnostics real-time PCR assay $(n=605)$.

\begin{tabular}{|c|c|c|c|c|}
\hline $\begin{array}{c}\text { SybrGreen } \\
\text { PCR-Based } \\
\text { Screening Resu }\end{array}$ & \multicolumn{2}{|c|}{$\begin{array}{l}\text { Result of Hybridization } \\
\text { Probe-Based Confirmatory } \\
\text { Testing Applying the } \\
\text { Altona Diagnostics Assay }\end{array}$} & $\begin{array}{c}\text { Diagnostic } \\
\text { Interpretation } \\
\text { Assumed as "True } \\
\text { Result" Considering } \\
\text { Both PCR Reactions }\end{array}$ & Number $(n)$ \\
\hline \multirow{2}{*}{ P. falciparum } & \multicolumn{2}{|c|}{ P. falciparum } & P. falciparum & 153 \\
\hline & \multicolumn{2}{|c|}{ Negative } & P. falciparum * & 12 \\
\hline \multirow{4}{*}{ Negative } & \multicolumn{2}{|c|}{ P. falciparum } & P. falciparum & 63 \\
\hline & \multicolumn{2}{|c|}{ P. malariae } & P. malariae & 3 \\
\hline & \multicolumn{2}{|c|}{ P. ovale complex } & P. ovale complex & 3 \\
\hline & \multicolumn{2}{|c|}{ Negative } & Negative & 142 \\
\hline \multirow{4}{*}{$\begin{array}{l}\text { Distorted melting } \\
\text { curves within the } \\
\text { expected temperature } \\
\text { range }\end{array}$} & \multicolumn{2}{|c|}{ P. falciparum } & P. falciparum & 210 \\
\hline & \multicolumn{2}{|c|}{$\begin{array}{c}\text { P. falciparum/ } \\
\text { P. malariae co-infection }\end{array}$} & $\begin{array}{l}\text { P. falciparum /P. malariae } \\
\text { co-infection }\end{array}$ & e \\
\hline & \multicolumn{2}{|c|}{ P. malariae } & P. malariae & 1 \\
\hline & \multicolumn{2}{|c|}{ Negative } & Negative & 14 \\
\hline \multicolumn{5}{|c|}{$\begin{array}{l}\text { *The interpretation was due to unambiguous melting curves in the SybrGreen-based screening PCR, strongly } \\
\text { suggesting incorrect results in the hybridization probe-based assay. } \\
\text { Table } 4 \text {. Distribution of Plasmodium species either by routine microscopy or PCR-based detection } \\
\text { in the incubated blood culture materials. Only samples are shown that had been assessed by both } \\
\text { microscopy and PCR }(n=2114) \text {. }\end{array}$} \\
\hline $\begin{array}{l}\text { Kind of } \\
\text { Infection }\end{array}$ & $\begin{array}{c}\text { Detected by } \\
\text { Routine } \\
\text { Microscopy, } n / n \\
\text { (\%) }\end{array}$ & $\begin{array}{l}\text { Detected by } \\
\text { Real-Time } \\
\text { PCR, } n / n(\%)\end{array}$ & $\begin{array}{l}\text { Concordance } \\
\text { of Routine } \\
\text { Microscopy } \\
\text { and PCR, } n / n \\
(\%)\end{array}$ & $\begin{array}{l}\text { Detected in Total } \\
\text { Combining } \\
\text { Routine } \\
\text { Microscopy and } \\
\text { Real-Time PCR, } \\
\quad n / n, \%\end{array}$ \\
\hline $\begin{array}{l}\text { Plasmodium } \\
\text { falciparum }\end{array}$ & $\begin{array}{c}711 / 2114 \\
(33.6 \%)\end{array}$ & $\begin{array}{c}558 / 2114 \\
(26.4 \%)\end{array}$ & $\begin{array}{c}1773 / 2114 \\
(83.9 \%)\end{array}$ & $806 / 2114(38.1 \%)$ \\
\hline Plasmodium vivax & $0 / 2114(0.0 \%)$ & $1 / 2114(0.1 \%)$ & $\begin{array}{c}2113 / 2114 \\
(99.9 \%)\end{array}$ & $1 / 2114(0.1 \%)$ \\
\hline $\begin{array}{l}\text { Plasmodium ovale } \\
\text { complex }\end{array}$ & 0/2114 (0.0\%) & $10 / 2114(0.5 \%)$ & $\begin{array}{c}2104 / 2114 \\
(99.5 \%)\end{array}$ & $10 / 2114(0.5 \%)$ \\
\hline $\begin{array}{l}\text { Plasmodium } \\
\text { malariae }\end{array}$ & $7 / 2114(0.3 \%)$ & $95 / 2114(4.5 \%)$ & $\begin{array}{l}2018 / 2114 \\
(95.5 \%)\end{array}$ & $99 / 2114(4.7 \%)$ \\
\hline $\begin{array}{l}\text { Plasmodium spp. } \\
\text { (not further } \\
\text { discriminated) }\end{array}$ & $1 / 2114(0.1 \%)$ & 0/2114 (0.0\%) & $\begin{array}{c}2113 / 2114 \\
(99.9 \%)\end{array}$ & $1 / 2114(0.1 \%)$ \\
\hline $\begin{array}{l}\text { Infection with } \\
\text { more than one } \\
\text { Plasmodium spp. }\end{array}$ & $13 / 2114(0.6 \%)^{1}$ & $\begin{array}{c}4 / 2114(0.2 \%) \\
2\end{array}$ & $\begin{array}{c}2097 / 2114 \\
(99.20 \%)\end{array}$ & $17 / 2114(0.8 \%)$ \\
\hline
\end{tabular}

${ }^{1}$ Details of mixed infections as detected by routine microscopy: P. malariae and P. falciparum ( $\left.n=12\right)$, P. falciparum and P. ovale complex $(n=1) .{ }^{2}$ Details of mixed infections as detected by real-time PCR: P. malariae and P. falciparum $(n=4)$. 
Focusing on quantitative parameters, microscopically diagnosed parasitemia ranged from the detection limit $(<50$ parasite $/ \mu \mathrm{L})$ to $1,859,200$ parasites $/ \mu \mathrm{L}$, with a mean of 108,771 parasites per $\mu \mathrm{L}$ ( \pm standard deviation SD 188,491 parasites per $\mu \mathrm{L}$ ) and a median of 29,917 parasites per $\mu \mathrm{L}$ in a left-shifted distribution. Recorded Ct-values of the SybrGreenbased screening PCR ranged from 15 to 37 (mean \pm SD: $27.71 \pm 4.10$; median: 28 ).

All 11 P. ovale complex infections as identified within the 2321 samples were subjected to real-time PCR-based discrimination of P. ovale curtisi and P. ovale wallikeri. Thereby, $P$. ovale curtisi was identified in two instances, and P. ovale wallikeri was identified in six instances, while discrimination failed in three instances.

\subsection{Agreement of Real-Time PCR and Routine Microscopy}

Agreement of real-time PCR and routine microscopy results was calculated both for routine microscopy as the reference and for a combined reference comprising routine microscopy and real-time PCR. As indicated in Table 5, both the agreement of positive results and the predictive value of real-time PCR for negative results in the reference were lower than recorded for routine microscopy if a combined reference comprising both positive real-time PCR results and routine microscopy results was used. If routine microscopy was applied as the reference, the agreement of positive results of real-time PCR was even lower, and the agreement of negative results and predictive value for positive results in the reference were low as well.

Table 5. Agreement of positive and negative real-time PCR results with routine microscopy as the reference and with a combined reference comprising routine microscopy and real-time PCR regarding malaria detection at the genus level $(n=2114)$.

\begin{tabular}{cccc}
\hline Criterium & $\begin{array}{c}\text { Real-Time PCR } \\
\text { (with Routine } \\
\text { Microscopy as the } \\
\text { Reference) }\end{array}$ & $\begin{array}{c}\text { Real-time PCR } \\
\text { (with a Combined } \\
\text { Reference of } \\
\text { Routine } \\
\text { Microscopy and } \\
\text { Real-Time PCR) }\end{array}$ & $\begin{array}{c}\text { Routine Microscopy } \\
\text { (with a Combined } \\
\text { Reference of } \\
\text { Routine Microscopy } \\
\text { and Real-Time PCR) }\end{array}$ \\
\hline $\begin{array}{c}\text { Agreement of positive } \\
\text { results, } n / n(\%)\end{array}$ & $542 / 732(74.0 \%)$ & $668 / 858(77.9 \%)$ & $732 / 858(85.3 \%)$ \\
\hline $\begin{array}{c}\text { Agreement of negative } \\
\text { results, } n / n(\%)\end{array}$ & $1256 / 1382(90.9 \%)$ & n.a. & n.a. \\
\hline $\begin{array}{c}\text { Predictive value for } \\
\text { positive results in the } \\
\text { chosen reference, } n / n(\%)\end{array}$ & $542 / 668(81.1 \%)$ & n.a. & n.a. \\
\hline $\begin{array}{c}\text { Predictive value for } \\
\text { negative results in the } \\
\text { reference, } n / n(\%)\end{array}$ & $1256 / 1446(86.9 \%)$ & $1256 / 1446(86.9 \%)$ & $1256 / 1382(90.9 \%)$ \\
\hline n.a. $=$ not applicable. & & & \\
\hline
\end{tabular}

\subsection{Analysis of the Distribution of Ct-Values and Parasitemia}

SybrGreen-based screening PCR Ct-values of Plasmodium spp. detections with concordant and discordant detections in routine microscopy were compared and the results are outlined in Table 6. Ct values of the commercial Altona Diagnostics PCR were not included as not all samples were assessed applying this diagnostic approach. Mixed infections were excluded from this analysis. Slightly higher average $\mathrm{Ct}$ values in PCR-positive but routine microscopy negative samples suggested a higher baseline parasitemia as the limit of detection for routine microscopy compared to PCR. However, overlapping standard deviation (SD) ranges indicated only a minor effect. Focusing on parasitemia, lower average parasitemia of $P$. falciparum but higher average parasitemia of $P$. malariae were recorded in routine microscopy-positive, PCR-negative samples compared to samples that were positive in both diagnostic approaches (Table 7). Correlation of the Ct values of the 
SybrGreen-based screening PCR and microscopically observed parasitemia resulted in a Spearman $r$ value of -0.42 with a significance level of $p<0.0001$.

Table 6. SybrGreen-based screening PCR Ct values of Plasmodium spp. detections for samples that were positive in both routine microscopy and real-time PCR and in real-time PCR only $(n=2114)$.

\begin{tabular}{ccc}
\hline Species & $\begin{array}{c}\text { Recorded Ct-Values in Case of } \\
\text { Concordance of Routine } \\
\text { Microscopy and PCR, } n ; \\
\text { Mean }( \pm \text { SD); Median } \\
\text { (Minimum, Maximum) }\end{array}$ & $\begin{array}{c}\text { Recorded Ct-Values with } \\
\text { Diagnosis Based on PCR only, } n ; \\
\text { Mean ( } \pm \text { SD); Median } \\
\text { (Minimum, Maximum) }\end{array}$ \\
\hline P. falciparum & $n=465 ; 26,4( \pm 3.9) ; 26.5(15.4,37.0)$ & $n=562 ; 26.8( \pm 3.9) ; 27.0(15.0,37.0)$ \\
\hline P. vivax & $n=0 ;$ n.a. & $n=1 ; 32.4( \pm 0) ; 32.4(32.4,32.4)$ \\
\hline P. ovale complex & $n=0 ;$ n.a. & $n=10 ; 33.0( \pm 2.2) ; 33.2(29.0,35.7)$ \\
\hline P. malariae & $n=3 ; 30.6( \pm 1.5) ; 31.5(28.5,31.7)$ & $n=99 ; 31.7( \pm 2.1) ; 31.7(24.8,36.3)$ \\
\hline n.a. $=$ not applicable. & &
\end{tabular}

Table 7. Microscopically diagnosed parasitemia in parasites $/ \mu \mathrm{L}$ as recorded for Plasmodium spp. detections in both routine microscopy and real-time PCR and in routine microscopy only.

\begin{tabular}{|c|c|c|}
\hline Species & $\begin{array}{l}\text { Recorded Parasitemia in Case of } \\
\text { Concordance of Routine } \\
\text { Microscopy and PCR, } n \text {; } \\
\text { Mean }( \pm \text { SD); Median } \\
\text { (Minimum, Maximum) }\end{array}$ & $\begin{array}{l}\text { Recorded Parasitemia with } \\
\text { Diagnosis Based on Routine } \\
\text { Microscopy only, } n \text {; Mean }( \pm \mathrm{SD}) ; \\
\text { Median (Minimum, Maximum) }\end{array}$ \\
\hline P. falciparum & $\begin{array}{c}n=463 ; 142,554.1( \pm 213,046.9) \\
63,800(71,1,859,200)\end{array}$ & $\begin{array}{c}n=722 ; 109,950.5( \pm 189,177.7) \\
31,304(70,1,859,200)\end{array}$ \\
\hline P. vivax & $n=0 ;$ n.a. & $n=0 ;$ n.a. \\
\hline P. ovale complex & $n=0 ;$ n.a. & $n=0 ;$ n.a. \\
\hline P. malariae & $n=3 ; 665.3( \pm 645.4) ; 384(54,1558)$ & $\begin{array}{c}n=20 ; 36,100.3( \pm 70,620.7) ; 3079.5 \\
(54,272,160)\end{array}$ \\
\hline
\end{tabular}

n.a. $=$ not applicable.

\section{Discussion}

The study was performed to assess the suitability and reliability of real-time PCR from incubated blood culture material compared to traditional routine microscopy by reassessing historical samples from a previous epidemiological study [24-28]. As expected for a highly sensitive approach such as real-time PCR [4-6], its addition to traditional routine microscopy resulted in a considerable increase in malaria-positive samples compared to the microscopical approach alone. Not surprisingly, if routine microscopy was applied as a reference, real-time PCR was associated with a low agreement of negative results and a sub-optimal predictive value for positive results in the reference. However, if positive samples, either by routine microscopy or real-time PCR or both, were applied as a composite reference, agreement of positive results obtained with real-time PCR was increased while agreement of positive results obtained with routine microscopy was decreased. The predictive value of routine microscopy for negative results in the references was slight compared to real-time PCR and the overall concordance between routine microscopy and real-time PCR was rather low. Regarding the cycle threshold $(\mathrm{Ct})$ values and the microscopically observed parasitemia, only a weak-to-moderate negative correlation was recorded, a result that is well in line with previous observations [2].

The observed discordance regarding the positive results in real-time PCR and routine microscopy requires further interpretation. Real-time PCR on EDTA blood is more sensitive than routine microscopy [2,32], which could explain the samples additionally detected by real-time PCR but not by routine microscopy in our study. It must be considered, 
however, that the samples used were diluted in blood culture medium, whereby DNA might have been degraded during the incubation step and, further, intracellular parasite DNA could have been lost during the pre-analytic centrifugation steps. Such DNA loss was not observed in a previous real-time PCR screening for invasive enteropathogenic and other bacteria $[24,25]$ with the same samples, in which even higher sensitivity of realtime PCR was seen compared to bacterial growth on agar plates. However, in contrast to bacterial DNA, plasmodial DNA is not enriched in blood culture and intracellular parasites may easily become lost during the centrifugation step. These combined effects potentially reduced the agreement of positive real-time PCR from blood culture material with the applied references compared to real-time PCR from EDTA blood or fresh capillary blood, respectively. According to previous studies [17,37], capillary blood buffy coat samples proved to be particularly reliable regarding the differentiation and quantification of plasmodia [37], while differences between capillary and venous blood films are still controversial [17,37] and the time of sampling under therapy is also known to affect the recorded parasitemia [38]. Conclusions on differences in the reliability of molecular malaria detection with incubated blood culture materials and other suboptimal sample materials such as dried blood spots [19], rapid diagnostic tests [20], microscopical slides [21] or stool [22] are, unfortunately, difficult to draw, because the applied study designs varied considerably. Of note, malaria-positive samples were recognized by real-time PCR at the detection limit of 50 parasites $/ \mu \mathrm{L}$ and in the case of submicroscopic malaria as well in our study. This finding speaks in favor of the alternative hypothesis that factors other than just parasitemia could have affected the real-time PCR's reliability from the assessed blood culture media, leading to stochastic PCR failure rather than a reduced limit of detection. The slightly higher cycle threshold values in PCR-positive routine microscopy-negative samples point in this direction as well.

Positive samples that were identified by routine microscopy but came up negative by PCR are much more difficult to explain than vice versa. Firstly, inhibition-control PCR, as included in the commercial Altona Diagnostics real-time PCR approach, did not indicate relevant inhibition within the assessed routine microscopy-positive but PCR-negative samples. Thus, PCR inhibition did not play a relevant role in these reactions. In line with this, commercial Altona Diagnostics real-time PCR mostly reproduced the results of SybrGreen-based screening PCR in case of conclusive melting curves. There was only a minority of 14 samples that were unambiguously positive by SybrGreen-based screening PCR but missed by the hybridization probe-based confirmatory Altona Diagnostics realtime PCR. This discrepancy can be explained by a slight discordance in diagnostic accuracy of the applied PCR assays, as reported recently [32]. Secondly, the comparison of the parasitemia observed microscopically in PCR-positive and PCR-negative samples did not exhibit a relevantly lower parasitemia in samples missed by PCR. These two arguments raise the question as to whether false-positive routine malaria microscopy results may at least have partially contributed to the proportion of routine microscopy-positive but PCR-negative samples. Unfortunately, this question is difficult to answer in the absence of a "true gold standard" that has a perfect diagnostic accuracy [39]. However, the described information speaks in favor of a considerable proportion of false-positive samples among the routine microscopy-positive but PCR-negative samples. If this assumption was true, the "true" agreement of positive real-time PCR from blood culture material would be even higher than recorded in this study. Hypothetically, high concentrations of bacterial DNA from bacteria grown in the blood samples might also have interacted with the malaria PCR reactions. However, correlations of bacterial detections in the blood cultures and malaria PCR results were not attempted in this study. As stated above in the "Materials and Methods" chapter, bacterial culture and pan-bacterial PCR with subsequent Sanger sequencing provided considerably different positivity rates for the assessed blood culture materials [24,25]. Similar cycle threshold $(\mathrm{Ct})$ values made the discrimination of missed bacterial growth due to inappropriate pre-analytic conditions in the tropics and secondary contamination of the samples unreliable. Due to the resulting uncertainty, the positivity 
of blood culture material for bacterial pathogens was not included as a parameter in the anonymous data collection for this study. Of note, cross-reaction of the malaria PCRs with bacterial DNA was not excluded, although the eukaryotic DNA sequences serving as targets for the malaria PCRs, which do not occur in prokaryotic cells, do not make this option very likely.

Of note, there was only a minor difference between the recorded cycle threshold $(\mathrm{Ct})$ values of samples, which were concordantly positive by routine microscopy and PCR as compared to the PCR-positive routine microscopy-negative samples. This finding confirms a previous report on a weak association between microscopically observed parasitemia in EDTA blood and recorded Ct-values [2], which was the same as the recorded weak-tomoderate correlation in this study, as stated above.

Of further interest, SybrGreen-based screening PCR from blood culture specimens resulted in a high proportion of distorted melting curves, a phenomenon that is virtually absent in EDTA blood samples in our experience [31,32]. This required hybridization probebased confirmatory testing for a discrimination at the species level, involving the application of the Altona Diagnostics assay. Thereby, a minority of 14 samples could not be confirmed as malaria positive. One reason could be that those 14 SybrGreen-based screening PCR signals were indeed non-specific, as decided for the interpretation algorithm. An alternative hypothesis is that the hybridization probe-based Altona Diagnostics confirmatory approach might have missed some "true positive" samples itself. This is not unlikely due to the slight discordance in diagnostic accuracy of the applied PCR assays, as reported recently [32]. However, because the study design was based on the SybrGreen PCR-based screening approach and the hybridization probe-based Altona Diagnostics confirmatory approach was added only in the case of questionable SybrGreen-based screening PCR results, this question cannot be answered. It remains unclear as to how many samples would have been finally missed by the Altona Diagnostics confirmation PCR if it had been used as the screening approach. This is an admitted limitation of the study, as detailed below.

As a side finding of the study, sympatric co-occurrence of $P$. ovale wallikeri and $P$. ovale curtisi could be confirmed for Ghana; a finding matching the results obtained from travel returnees from Western Africa [3]. Of note, a minority of samples did not contain sufficient target DNA to allow a conclusive discrimination. Further, the occurrence of $P$. vivax in Ghana is considered as not confirmed so far [40]. In this study, two real-time PCR signals that were suggestive of the abundance of low amounts of P. vivax DNA, but no microscopical proof, were recorded. One of the two real-time PCR signals occurred in a sample completely without microscopic assessment. These findings are indicative of either submicroscopic $P$. vivax occurrence at very low frequency in Ghana or solitary non-specific real-time PCR results as an alternative hypothesis.

The study has a number of limitations. First, the applied residual sample materials were old, potentially reducing the diagnostic reliability. However, appropriate storage at $-80{ }^{\circ} \mathrm{C}$ was assured, making severe sample age-associated DNA degradation unlikely. Most likely still adequate sample quality was also suggested by the fact that the inhibition control assay of the commercial Altona Diagnostics PCR kit did not indicate any relevant sample inhibition and, thus, degradation products potentially interfering with nucleic acid amplification did not play a major role. This finding further supports our decision on working with historic residual sample materials. As a second limitation, the confirmatory commercial Altona Diagnostics real-time PCR assay, including the inhibition control PCR reaction, could not be performed for all samples for economic reasons. Third, the study did not contain a reference with perfect diagnostic accuracy, so only comparative evaluations could be performed.

\section{Conclusions}

The study was conducted to answer the question of whether real-time PCR from incubated blood culture material can reliably identify the presence or absence of malaria parasitemia at the time of the sample acquisition for forensic purposes. In spite of the 
limitations resulting from the use of historic samples, it has to be concluded that real-time PCR from such specimens is not accurate enough. Accordingly, a diagnostic attempt with incubated blood culture material is only justified in cases in which initially missed malaria infections shall be confirmed for the time point of blood culture acquisition due to forensic reasons and more suitable samples are unavailable. Such PCR results have to be interpreted with care since the results of real-time PCR from blood culture material are considerably less reliable than from EDTA blood [2,32] or fresh capillary blood [17]. Compared to easy-to-collect, more reliable samples such as EDTA blood [2,32], incubated blood culture materials are also poor specimens for epidemiological assessments requiring diagnostic accuracy-adjusted prevalence estimations [41].

Author Contributions: Conceptualization, H.F., U.L. and D.D.; methodology, F.W., H.F., U.L. and D.D.; software, F.W. and H.F.; validation, F.W. and H.F.; formal analysis, F.W. and H.F.; investigation, F.W. and H.F.; resources, H.F., R.M.H. and D.D.; data curation, F.W., W.L., O.M.-A. and D.D.; writingoriginal draft preparation, H.F.; writing — review and editing, F.W., R.M.H., W.L., U.L., O.M.-A., H.F. and D.D.; visualization, H.F.; supervision, H.F.; project administration, H.F.; funding acquisition, H.F. and U.L. All authors have read and agreed to the published version of the manuscript.

Funding: The experiments were funded by grant 36K2-S-45 1922, the "Evaluation and optimization of molecular diagnostic tests for tropical parasitic diseases for surveillance and risk assessment purposes in tropical deployment settings-a German-French cooperation project between the German Armed Forces Hospital Hamburg and the Military Hospital Laveran, Marseille" of the German Ministry of Defense (MoD), awarded to Hagen Frickmann. The sponsors did not have any role in the collection, analysis, or interpretation of data, in the writing of the report, or in the decision to submit the article for publication.

Institutional Review Board Statement: Ethical clearance, as obtained by the medical association of Hamburg, Germany, (reference number: WF-011/19; obtained on 11 March 2019), allowed the anonymous use of residual sample materials for test comparison purposes without informed consent. The study was conducted according to the guidelines of the Declaration of Helsinki.

Informed Consent Statement: Not applicable.

Data Availability Statement: All relevant data are provided within the manuscript. Raw data can be provided on reasonable request.

Acknowledgments: Simone Priesnitz and Annett Michel are gratefully acknowledged for their excellent technical assistance.

Conflicts of Interest: The authors declare no conflict of interest. The funders had no role in the design of the study; in the collection, analyses, or interpretation of data; in the writing of the manuscript, or in the decision to publish the results.

\section{Appendix A}

Table A1. Sequence inserts for the positive control plasmids of the SybrGreen-based malaria screening PCR included in a pEX-A128 vector backbone as applied for the definition of the melting temperatures.

Positive Control Insert Based on the P. falciparum Sequence according to the NCBI GenBank Accession Number JQ627151.1.

5'-TTCCGATAACGAACGAGATCTTAACCTGCTAATTAGCGGCGAGTACACTATATTCTTATTT-

GAAATTGAACATAGGTAACTATACATTTATTCAGTAATCAAATTAGGATATTTTTATTAAAATATCCTTTTCCC TGTTCTACTAATAATTTGTTTTTTACTCTATTTCTCTCTTCTTTTAAGAATGTACTTGCTTGATTGAAAAGCTTCTTAGAGGAACATTGTG-3'

Positive Control Insert Based on the P. malariae Sequence According to the NCBI GenBank Accession Number EF467831.1.

5'-TTCCGATAACGAACGAGATCTTAACCTGCTAATTAGCGGTAAATACACTA-

TATTCTTAAGTGAAATTAGAATATAGATAAATTGTGCTAATTTTGATTAAAATATTAGAATGTTTTTTTTAAT

AAAAACGTTCTTTTCCCTTTTTTTCTTAATTATGCATATTTATTTTTTTTCTTCTTTT-

GCATAAGAATGTATTTGCTTAATTGTAAAGCTTCTTAGAGGAACGATGTG-3'

Positive Control Insert Based on the P. vivax Sequence According to the NCBI GenBank Accession Number JQ627158.1. 
Table A1. Cont.

Positive Control Insert Based on the P. falciparum Sequence according to the NCBI GenBank Accession Number JQ627151.1.

5'-TTCCGATAACGAACGAGATCTTAACCTGCTAATTAGCGGCAAATACGATATATTCTTAC-

GTGGGACTGAATTCGGTTGATTTGCTTACTTCGAAGAAAATATTGGGATACGTAACAGTTTCCCTTTCCCTTT TCTACTTAGTTCGCTTTTCATACTGTTTCTTTTTCGCGTAAGAATGTATTTGCTTGATTGTAAAGCTTCTTAGAGGAACGATGTG-3'

Positive Control Insert Based on the P. ovale complex Sequence According to the NCBI GenBank Accession Number KF018659.1.

5'-TTCCGATAACGAACGAGATCTTAACCTGCTAATTAGCGGCGAATACGTTATATTCCTACTT-

GAAATTGAATATAGCTGAATTTGCTTATTTTGAAGAATATATTAGGATACATTATAGTGTCCTTTTCCCTTTT

CTACTTAATTCGCTATTCATGCTGTTTCTTTTTTGTGTAGGAATGTATTCGTTTGATTGTAAAGCTTCTTAGAGGAACGATGTG-3'

Positive Control Insert Based on the P. knowlesi Sequence According to the NCBI GenBank Accession Number KJ917904.1.

5'-TTCCGATAACGAACGAGATCTTAACCTGCTAATTAGCGGCAAATACGATATA-

TTCTTATGTAGAATTGAATATAGTGGATTTGTTAGATTTTGAAGAAAATATTGGAATTACGTTAAATGTG

ATTCCTTTCCCTTTTCTACTTAATTTACATTTCCATCTATTTCTTTTTTGCG-

TATGAATGTATTTGCTTGATTGTAAAGCTTCTTAGAGGAACGATGTG-3'

Table A2. Sequence inserts for the positive control plasmids of the differentiation PCR for the discrimination of $P$. ovale curtisi and P. ovale wallikeri included in a pEX-A128 vector backbone.

Positive Control Insert Based on the P. ovale curtisi Sequence according to the NCBI GenBank Accession Number KX672023.1.

5'-AATCTTAACCATAAACTATGCCGACTAGGTTTTGGATGAAACATTTTTAAATAA-

GAAAATTCCTTTCGGGGAAATTTCTTAGATTGCTTCTTTCAGTACCTTATGAGAAATCAAAGTCTTTGGGTTC-3'

Positive Control Insert Based on the P. ovale wallikeri Sequence According to the NCBI GenBank Accession Number MG241227.1.

5'-AATCTTAACCATAAACTATGCCGACTAGGTTTTGGATGAAAGATTTTTAAATAA-

GAAAATTCCTTTTGGAAATTTCTTAGATTGCTTCCTTCAGTACCTTATGAGAAATCAAAGTCTTTGGGTTC-3'

Table A3. Distribution of Plasmodium species by routine microscopy or PCR-based detection in the incubated blood culture materials $(n=2321)$.

\begin{tabular}{|c|c|c|c|c|c|c|c|}
\hline Real-Time & $\begin{array}{l}\text { Plasmodium } \\
\text { falciparum, } n, \\
\text { Mean Ct } \\
\text { ( } \pm \text { SD), } \\
\text { Parasitemia } \\
\text { ( } \pm \text { SD) }\end{array}$ & $\begin{array}{l}\text { Plasmodium } \\
\text { vivax, } n\end{array}$ & $\begin{array}{l}\text { Plasmodium } \\
\text { ovale } \\
\text { Complex, } n\end{array}$ & $\begin{array}{c}\text { Plasmodium } \\
\text { malariae, } n, \\
\text { Mean Ct } \\
( \pm \text { SD), } \\
\text { Parasitemia } \\
( \pm \text { SD })\end{array}$ & $\begin{array}{c}\text { Plasmodium spp. } \\
\text { (not Further } \\
\text { Discriminated), } n, \\
\text { Mean Ct }( \pm \text { SD), } \\
\text { Parasitemia }( \pm \text { SD) }\end{array}$ & $\begin{array}{l}\text { Not } \\
\text { Performed, } n \text {, } \\
\text { Mean Ct } \\
( \pm \text { SD })\end{array}$ & $\begin{array}{c}\text { Negative, } n \text {, } \\
\text { Mean Ct } \\
( \pm S D)\end{array}$ \\
\hline Plasmodium falciparum & $\begin{array}{c}465 ; \\
26.42( \pm 3.9) \\
142,554.06 \\
( \pm 213,046.92)\end{array}$ & & & & $\begin{array}{c}5 ; \\
25.34( \pm 2.04) \\
118,951.20 \\
( \pm 96,214.95)\end{array}$ & $\begin{array}{c}44 \\
27.27( \pm 3.87)\end{array}$ & $\begin{array}{c}92 ; \\
28.64( \pm 3.29)\end{array}$ \\
\hline Plasmodium vivax & & 0 & & & 0 & $\begin{array}{c}1 ; \\
35.66^{(}( \pm 0)\end{array}$ & $\begin{array}{c}1 ; \\
32.35( \pm 0)\end{array}$ \\
\hline Plasmodium ovale complex & & & 0 & & $\begin{array}{c}2 ; \\
32.27( \pm 3.27) \\
8322.50( \pm 4573.50)\end{array}$ & $\begin{array}{c}1 ; \\
30.00( \pm 0)\end{array}$ & 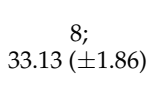 \\
\hline Plasmodium malariae & & & & $\begin{array}{c}3 \\
30.55( \pm 1.46) \\
665.33 \\
( \pm 645.43)\end{array}$ & $\begin{array}{c}2 ; \\
28.83( \pm 0.91) \\
2168.50( \pm 1350.50)\end{array}$ & $\begin{array}{c}12 \\
32.47( \pm 1.77)\end{array}$ & $\begin{array}{c}94 ; \\
31.78( \pm 2.10)\end{array}$ \\
\hline Negative & $\begin{array}{c}248 ; \\
0( \pm 0) \\
51,460 \\
( \pm 116,560.22)\end{array}$ & 0 & 0 & $\begin{array}{c}4 ; \\
0( \pm 0) ; \\
23,964.50 \\
( \pm 39,550.28)\end{array}$ & $\begin{array}{c}5 \\
0( \pm 0) \\
2103.25( \pm 1482.74)\end{array}$ & 149 & 1256 \\
\hline
\end{tabular}




\section{References}

1. Kotepui, M.; Masangkay, F.R.; Kotepui, K.U.; De Jesus Milanez, G. Misidentification of Plasmodium ovale as Plasmodium vivax malaria by a microscopic method: A meta-analysis of confirmed P. ovale cases. Sci. Rep. 2020, 10, 21807. [CrossRef] [PubMed]

2. Frickmann, H.; Wegner, C.; Ruben, S.; Behrens, C.; Kollenda, H.; Hinz, R.; Rojak, S.; Schwarz, N.G.; Hagen, R.M.; Tannich, E. Evaluation of the multiplex real-time PCR assays RealStar malaria S \& T PCR kit 1.0 and FTD malaria differentiation for the differentiation of Plasmodium species in clinical samples. Travel Med. Infect. Dis. 2019, 31, 101442.

3. Frickmann, H.; Wegner, C.; Ruben, S.; Loderstädt, U.; Tannich, E. A comparison of two PCR protocols for the differentiation of Plasmodium ovale species and implications for clinical management in travellers returning to Germany: A 10-year cross-sectional study. Malar. J. 2019, 18, 272. [CrossRef] [PubMed]

4. $\quad$ Bourgeois, N.; Boutet, A.; Bousquet, P.J.; Basset, D.; Douard-Enault, C.; Charachon, S.; Lachaud, L. Comparison of three real-time PCR methods with blood smears and rapid diagnostic test in Plasmodium sp. infection. Clin. Microbiol. Infect. 2010, 16, 1305-1311. [CrossRef] [PubMed]

5. Dormond, L.; Jaton-Ogay, K.; de Vallière, S.; Genton, B.; Bille, J.; Greub, G. Multiplex real-time PCR for the diagnosis of malaria: Correlation with microscopy. Clin. Microbiol. Infect. 2011, 17, 469-475. [CrossRef] [PubMed]

6. Picot, S.; Cucherat, M.; Bienvenu, A.L. Systematic review and meta-analysis of diagnostic accuracy of loop-mediated isothermal amplification (LAMP) methods compared with microscopy, polymerase chain reaction and rapid diagnostic tests for malaria diagnosis. Int. J. Infect. Dis. 2020, 98, 408-419. [CrossRef] [PubMed]

7. Shokoples, S.E.; Ndao, M.; Kowalewska-Grochowska, K.; Yanow, S.K. Multiplexed real-time PCR assay for discrimination of Plasmodium species with improved sensitivity for mixed infections. J. Clin. Microbiol. 2009, 47, 975-980. [CrossRef] [PubMed]

8. Grossman, T.; Schwartz, E.; Vainer, J.; Agmon, V.; Glazer, Y.; Goldmann, D.; Marva, E. Contribution of real-time PCR to Plasmodium species identification and to clinical decisions: A nationwide study in a non-endemic setting. Eur. J. Clin. Microbiol. Infect. Dis. 2017, 36, 671-675. [CrossRef]

9. Kotepui, M.; Kotepui, K.U.; De Jesus Milanez, G.; Masangkay, F.R. Summary of discordant results between rapid diagnosis tests, microscopy, and polymerase chain reaction for detecting Plasmodium mixed infection: A systematic review and meta-analysis. Sci. Rep. 2020, 10, 12765. [CrossRef]

10. Danwang, C.; Kirakoya-Samadoulougou, F.; Samadoulougou, S. Assessing field performance of ultrasensitive rapid diagnostic tests for malaria: A systematic review and meta-analysis. Malar. J. 2021, 20, 245. [CrossRef]

11. Zainabadi, K. Ultrasensitive Diagnostics for Low-Density Asymptomatic Plasmodium falciparum Infections in Low-Transmission Settings. J. Clin. Microbiol. 2021, 59, e01508-20. [CrossRef]

12. Kamaliddin, C.; Sutherland, C.J.; Houze, S.; Cottrell, G.; Briand, V.; Mogollon, D.C.; Pillai, D.R. The role of ultra-sensitive molecular methods for detecting malaria-The broader perspective. Clin. Infect. Dis. 2021, 7, e1387-e1390. [CrossRef] [PubMed]

13. Prusty, D.; Gupta, N.; Upadhyay, A.; Dar, A.; Naik, B.; Kumar, N.; Prajapati, V.K. Asymptomatic malaria infection prevailing risks for human health and malaria elimination. Infect. Genet. Evol. 2021, 93, 104987. [CrossRef] [PubMed]

14. Mbanefo, A.; Kumar, N. Evaluation of Malaria Diagnostic Methods as a Key for Successful Control and Elimination Programs. Trop. Med. Infect. Dis. 2020, 5, 102. [CrossRef]

15. Whittaker, C.; Slater, H.; Nash, R.; Bousema, T.; Drakeley, C.; Ghani, A.C.; Okell, L.C. Global patterns of submicroscopic Plasmodium falciparum malaria infection: Insights from a systematic review and meta-analysis of population surveys. Lancet Microbe 2021, 2, e366-e374. [CrossRef]

16. Deen, J.; Mukaka, M.; von Seidlein, L. What is the yield of malaria reactive case detection in the Greater Mekong Sub-region? A review of published data and meta-analysis. Malar. J. 2021, 20, 131. [CrossRef]

17. Mischlinger, J.; Pitzinger, P.; Veletzky, L.; Groger, M.; Zoleko-Manego, R.; Adegnika, A.A.; Agnandji, S.T.; Lell, B.; Kremsner, P.G.; Tannich, E.; et al. Use of Capillary Blood Samples Leads to Higher Parasitemia Estimates and Higher Diagnostic Sensitivity of Microscopic and Molecular Diagnostics of Malaria Than Venous Blood Samples. J. Infect. Dis. 2018, 218, 1296-1305. [CrossRef]

18. Danwang, C.; Noubiap, J.J.; Souopgui, J.; Gaudart, J.; Yombi, J.C.; Robert, A. Accuracy of malaria diagnostic tests performed on non-invasively collected samples: A systematic review and meta-analysis. BMJ Glob. Health 2021, 6, e005634. [CrossRef]

19. Mahittikorn, A.; Masangkay, F.R.; Kotepui, K.U.; De Jesus Milanez, G.; Kotepui, M. Comparative performance of PCR using DNA extracted from dried blood spots and whole blood samples for malaria diagnosis: A meta-analysis. Sci. Rep. 2021, 11, 4845. [CrossRef]

20. Morris, U.; Aydin-Schmidt, B.; Shakely, D.; Mårtensson, A.; Jörnhagen, L.; Ali, A.S.; Msellem, M.I.; Petzold, M.; Gil, J.P.; Ferreira, P.E.; et al. Rapid diagnostic tests for molecular surveillance of Plasmodium falciparum malaria -assessment of DNA extraction methods and field applicability. Malar. J. 2013, 12, 106. [CrossRef]

21. Cnops, L.; Van Esbroeck, M.; Bottieau, E.; Jacobs, J. Giemsa-stained thick blood films as a source of DNA for Plasmodium species-specific real-time PCR. Malar. J. 2010, 9, 370. [CrossRef] [PubMed]

22. Jirků, M.; Pomajbíková, K.; Petrželková, K.J.; Hůzová, Z.; Modrý, D.; Lukeš, J. Detection of Plasmodium spp. in human feces. Emerg. Inf. Dis. 2012, 18, 634-636. [CrossRef] [PubMed]

23. Loderstädt, U.; Hagen, R.M.; Hahn, A.; Frickmann, H. New Developments in PCR-Based Diagnostics for Bacterial Pathogens Causing Gastrointestinal Infections-A Narrative Mini-Review on Challenges in the Tropics. Trop. Med. Infect. Dis. 2021, 6, 96. [CrossRef] [PubMed] 
24. Frickmann, H.; Dekker, D.; Boahen, K.; Acquah, S.; Sarpong, N.; Adu-Sarkodie, Y.; Schwarz, N.G.; May, J.; Marks, F.; Poppert, S.; et al. Increased detection of invasive enteropathogenic bacteria in pre-incubated blood culture materials by real-time PCR in comparison with automated incubation in Sub-Saharan Africa. Scand. J. Infect. Dis. 2013, 45, 616-622. [CrossRef] [PubMed]

25. Frickmann, H.; Dekker, D.; Schwarz, N.G.; Hahn, A.; Boahen, K.; Sarpong, N.; Adu-Sarkodie, Y.; Halbgewachs, E.; Marks, F.; von Kalckreuth, V.; et al. 16S rRNA Gene Sequence-Based Identification of Bacteria in Automatically Incubated Blood Culture Materials from Tropical Sub-Saharan Africa. PLoS ONE 2015, 10, e0135923. [CrossRef]

26. Nielsen, M.V.; Sarpong, N.; Krumkamp, R.; Dekker, D.; Loag, W.; Amemasor, S.; Agyekum, A.; Marks, F.; Huenger, F.; Krefis, A.C.; et al. Incidence and characteristics of bacteremia among children in rural Ghana. PLoS ONE 2012, 7, e44063. [CrossRef]

27. Marks, F.; Adu-Sarkodie, Y.; Hünger, F.; Sarpong, N.; Ekuban, S.; Agyekum, A.; Nkrumah, B.; Schwarz, N.G.; Favorov, M.O.; Meyer, C.G.; et al. Typhoid fever among children, Ghana. Emerg. Infect. Dis. 2010, 16, 1796-1797. [CrossRef]

28. Schwarz, N.G.; Sarpong, N.; Hünger, F.; Marks, F.; Acquah, S.E.; Agyekum, A.; Nkrumah, B.; Loag, W.; Hagen, R.M.; Evans, J.A.; et al. Systemic bacteraemia in children presenting with clinical pneumonia and the impact of non-typhoid salmonella (NTS). BMC Infect. Dis. 2010, 10, 319. [CrossRef]

29. Giemsa, G. Eine Vereinfachung und Vervollkommnung meiner Methylenblau-Eosin-Färbemethode zur Erzielung der Romanowsky-Nocht'schen Chromatinfärbung. Cent. Für Bakteriol. 1904, 32, 307-313.

30. Trape, J.F. Rapid evaluation of malaria parasite density and standardization of thick smear examination for epidemiological investigations. Trans. R. Soc. Trop. Med. Hyg. 1985, 79, 181-184. [CrossRef]

31. Mangold, K.A.; Manson, R.U.; Koay, E.S.; Stephens, L.; Regner, M.; Thomson, R.B., Jr.; Peterson, L.R.; Kaul, K.L. Real-time PCR for detection and identification of Plasmodium spp. J. Clin. Microbiol. 2005, 43, 2435-2440. [CrossRef] [PubMed]

32. Altangerel, E.; Frickmann, H. Meta-analysis of the diagnostic performance characteristics of three commercial and one in-house nucleic acid amplification tests for malaria screening. J. Lab. Med. 2020, 44, 47-53. [CrossRef]

33. Bauffe, F.; Desplans, J.; Fraisier, C.; Parzy, D. Real-time PCR assay for discrimination of Plasmodium ovale curtisi and Plasmodium ovale wallikeri in the Ivory Coast and in the Comoros Islands. Malar. J. 2012, 11, 307. [CrossRef] [PubMed]

34. Calderaro, A.; Piccolo, G.; Perandin, F.; Gorrini, C.; Peruzzi, S.; Zuelli, C.; Ricci, L.; Manca, N.; Dettori, G.; Chezzi, C.; et al. Genetic polymorphisms influence Plasmodium ovale PCR detection accuracy. J. Clin. Microbiol. 2007, 45, 1624-1627. [CrossRef]

35. Calderaro, A.; Piccolo, G.; Gorrini, C.; Montecchini, S.; Rossi, S.; Medici, M.C.; Chezzi, C.; Snounou, G. A new real-time PCR for the detection of Plasmodium ovale wallikeri. PLoS ONE 2012, 7, e48033. [CrossRef] [PubMed]

36. Bossuyt, P.M.; Reitsma, J.B.; Bruns, D.E.; Gatsonis, C.A.; Glasziou, P.P.; Irwig, L.; Lijmer, J.G.; Moher, D.; Rennie, D.; De Vet, H.C.W.; et al. STARD 2015: An updated list of essential items for reporting diagnostic accuracy studies. BMJ 2015, 351, h5527. [CrossRef]

37. Abeje, G.; Gelaye, W.; Alemu, G. Comparison of capillary, venous and buffy coat blood samples in detecting Plasmodium species among malaria suspected patients attending at Hamusite health center. A cross-sectional study. BMC Infect. Dis. 2021, 21, 576. [CrossRef]

38. Carlsson, A.M.; Ngasala, B.E.; Dahlstrom, S.; Membi, C.; Veiga, I.M.; Rombo, L.; Abdulla, S.; Premji, Z.; Gil, J.P.; Bjorkman, A.; et al. Plasmodium falciparum population dynamics during the early phase of anti-malarial drug treatment in Tanzanian children with acute uncomplicated malaria. Malar. J. 2011, 10, 380. [CrossRef]

39. Hahn, A.; Podbielski, A.; Meyer, T.; Zautner, A.E.; Loderstädt, U.; Schwarz, N.G.; Krüger, A.; Cadar, D.; Frickmann, H. On detection thresholds-a review on diagnostic approaches in the infectious disease laboratory and the interpretation of their results. Acta Trop. 2020, 205, 105377. [CrossRef]

40. Brown, C.A.; Pappoe-Ashong, P.J.; Duah, N.; Ghansah, A.; Asmah, H.; Afari, E.; Koram, K.A. High frequency of the Duffy-negative genotype and absence of Plasmodium vivax infections in Ghana. Malar. J. 2021, 20, 99. [CrossRef]

41. Rogan, W.J.; Gladen, B. Estimating prevalence from the results of a screening test. Am. J. Epidemiol. 1978, 107, 71-76. [CrossRef] [PubMed] 